\title{
Virulence and aggressiveness of Phytophthora infestans isolates collected in Poland from potato and tomato plants identified no strong specificity
}

\author{
Anna M. Michalska • Sylwester Sobkowiak • \\ Bogdan Flis • Ewa Zimnoch-Guzowska
}

Accepted: 14 September 2015 /Published online: 18 September 2015

(C) The Author(s) 2015. This article is published with open access at Springerlink.com

\begin{abstract}
Late blight is a devastating and worldwide potato and tomato disease caused by Phytophthora infestans (Mont.) de Bary. The aim of the study was to compare $P$. infestans isolates collected from potato and tomato plants by determining their virulence, aggressiveness, and sporulation intensity on both hosts in reciprocal testing with the goal of elucidating possible host specialization of the pathogen. Isolates were multiplied on leaflets of their primary hosts. In total, 76 potato-derived P. infestans (P) isolates and 100 tomato-derived $P$. infestans $(\mathrm{T})$ isolates collected from 2005 to 2007 were studied in detached-leaflet assay experiments. Virulence was assessed on Black's potato differentials R1-R11 and cv. Bzura, as well as on the set of six tomato genotypes, namely cv. New Yorker $(P h-1$ gene), Solanum pimpinellifolium L 3708 (Ph-3), West Virginia'63 (Ph-2), West Virginia 700 (Ph-1, $P h-2)$, Ottawa 30 (Ph-1, Ph-2), and BALU-30 (Ph-1, Ph-2, fruit resistance). Aggressiveness scored as disease severity and sporulation intensity assessed on a $0-3$ grade scale were evaluated on leaflets of susceptible cultivars of both hosts. All 176 of the tested isolates were pathogenic to both hosts, indicating that extreme host specialization has not occurred. However, we did observe differences between $\mathrm{P}$ and $\mathrm{T}$ virulence spectra and their race structures supporting the notion of host adaptation
\end{abstract}

A. M. Michalska $\cdot$ S. Sobkowiak $\cdot$ B. Flis $\cdot$

E. Zimnoch-Guzowska $(\bowtie)$

Młochów Research Center, Plant Breeding and Acclimatization Institute - National Research Institute, 19 Platanowa str., 05-831 Młochów, Poland

e-mail: e.zimnoch-guzowska@ihar.edu.pl of $P$. infestans. $\mathrm{P}$ and $\mathrm{T}$ isolates were more frequently virulent to differentials of their own hosts. $P$ isolates had higher sporulation intensity on their own hosts than on tomato hosts, while for $\mathrm{T}$ isolates a similar sporulation intensity was observed on both hosts. Significantly stronger severity of the disease development on $\mathrm{T}$ testers was evoked by $\mathrm{T}$ isolates. All isolates showed stronger aggressiveness on susceptible potato than on susceptible tomato hosts, and the latter finding indicates a relatively greater suitability of potato host tissue for $P$. infestans pathogenicity. The host adaptation observed in this study was not conditioned by an ability to evoke disease, but rather by quantitative differences in pathogenic fitness. Genetic characterization of $\mathrm{P}$ and $\mathrm{T}$ populations is needed to place the present findings in a fuller context.

Keywords Black's differentials $\cdot$ Races $\cdot$ Pathogenicity Sporulation intensity $\cdot$ Host specialization $\cdot$ Late blight

\section{Introduction}

Late blight is a devastating disease of potato and tomato worldwide caused by the oomycete Phytophthora infestans (Mont.) de Bary. Observations of $P$. infestans pathogenicity in potato and tomato were first reported in the first half of the 20th century, when breeding for resistance to late blight in both species was initiated (Giddings and Berg 1919; Black 1952; Ferguson et al. 1952; Müller and Black 1952; Wilson and Gallegly 1955). Isolates of $P$. infestans were collected from host potato and tomato plants and the influence of the source 
host species identity on pathogenicity has been analyzed since the mid-20th century (Mills 1940; Gallegly 1952).

In recent decades, a large body of evidence has been gathered on the increased genetic variation and pathogenicity of $P$. infestans, when new populations were observed in a number of geographical areas owing presumably to pathogen migration (Fry 2008). An important aspect of the noted variation is this pathogen's variability in pathogenicity and virulence toward the host. Quantitative assessments of the fitness parameters of $P$. infestans have been conducted mostly with detached-leaf or leaflet assays (Goodwin et al. 1995; Legard et al. 1995; Świeżyński et al. 2000). Although $P$. infestans isolates are obtained from both potato and tomato, aggressiveness and virulence tests of the isolates have been evaluated primarily on potato differentials (Lebreton and Andrivon 1998; Dorrance et al. 1999; Vega-Sánchez et al. 2000; Derie and Inglis 2001; Klarfeld et al. 2009; Blandón-Diaz et al. 2012; Harbaoui et al. 2013). Aggressiveness and virulence of isolates from potato and tomato have also been compared on leaflets of the two host plants (Wilson and Gallegly 1955; Oyarzun et al. 1998; Lebreton et al. 1999; Jaime-Garcia et al. 2000; Cohen 2002; Knapova and Gisi 2002; Blandón-Diaz 2011). Sporulation of isolates has also been observed in a few experiments (Legard et al. 1995; Lebreton et al. 1999; Knapova and Gisi 2002; Klarfeld et al. 2009), indicating that the pathogen undergoes adaptation to the host. However, our understanding of the pathogenic specialization of the late blight pathogen is incomplete. Most isolates have been observed to be more aggressive to their original host species (Legard et al. 1995; Oyarzun et al.; 1998; Lebreton et al. 1999; Vega-Sánchez et al. 2000), with very rare exceptions (Blandón-Diaz 2011).

$P$. infestans isolates are often stored on artificial media and/or multiplied on potato tuber slices or leaves before being subjected to host adaptation experiments, even if the original host species of the isolate was tomato (Legard et al. 1995; Lebreton and Andrivon 1998; Dorrance et al. 1999; Vega-Sánchez et al. 2000). These procedures may influence aggressiveness and virulence results (Zarzycka 1995, 1996). Thus, the aim of this study was to evaluate host specificity of $P$. infestans isolates collected from potato and tomato fields and multiplied on their primary hosts. Reciprocal testing of the virulence, aggressiveness, and sporulation intensity of $P$. infestans isolates was performed on both hosts to elucidate possible host specialization of the pathogen.

\section{Materials and methods}

Host source plants

Isolates of $P$. infestans were collected over a period of 3 years in different regions of Poland. In 2005, isolates were collected from Małopolskie, Mazowieckie, Podkarpackie, and Świętokrzyskie. In 2006, isolates were collected from Wielkopolskie, Podkarpackie, and Pomorskie. In 2007, isolates were collected from Mazowieckie, Łódzkie, Podkarpackie, and Świętokrzyskie. They were collected from production fields, small gardens, and covered crops. In total, 76 isolates were collected from potato plants and 100 from tomato plants.

\section{Leaflets}

Leaflets used in the experiments were collected from cultivars and lines of both host species. The leaflet source plants were grown in a glasshouse or in plastic tunnels. Potato testers were planted three times along the vegetation season from May until August in peat-soil substrate in plastic pots of $23 \mathrm{~cm}$ diameter and were grown in a glasshouse. Tomato plants were grown from seeds, first transplanted into $10-\mathrm{cm}$ pots in the glasshouse and then in the beginning of June planted in the soil with a peat substrate in the plastic tunnel.

Lateral leaflets were collected from the middle part of 6-8-week-old potato plants and from the third to sixth fully expanded leaves counting from the top of 14-18week-old tomato plants. Specifically, potato leaflets were collected from a variety of $P$. infestans-susceptible cultivars, including Craigs Royal, Tarpan, Bintje, and Black's 11 differentials with single $\mathrm{R}$ genes ranging from R1 to R11 (Malcolmson and Black 1966; Skidmore and Shattock 1985), supplemented with cv. Bzura with $R 1$ and R2-like genes (Plich et al. 2015). Meanwhile tomato leaflets were collected from two susceptible cvs, namely Moneymaker or Lubań, and a set of six tomato differentials with various resistance genes: cv. New Yorker (Ph-1 gene; Cohen 2002), cv. West Virginia'63 (Ph-2 gene; Laterrot 1975), West Virginia 700 and Ottawa 30 accessions $(P h-1$ and $P h-2$ genes; Michalska and Pazio 2005), Solanum pimpinellifolium (previously Lycopersicon pimpinellifolium) L 3708 (Ph-3 gene; Black et al. 1996; Chunwongse et al. 2002), and the breeding line BALU-30 ( $P h-1$ and $P h-2$ genes supplemented with high fruit resistance). 
Determination of aggressiveness, virulence, and sporulation intensity

P. infestans isolates from potato were multiplied on leaflets of susceptible cvs Craigs Royal and Tarpan, whereas isolates from tomato were multiplied on leaflets of susceptible cvs Moneymaker and Lubań. Detached leaflets were placed in plastic boxes on wet wood wool. Five leaflets of each tomato and two leaflets of each potato differential were inoculated with each isolate being tested. All isolates were tested in two duplicate experiments.

Virulence defined as the capacity of a pathogen to infect a plant with one or more major genes for resistance (Niks et al. 2011) was assessed on Black's potato differentials R1-R11 and cv. Bzura, as well as on the set of six tomato differentials. Aggressiveness defined as the capacity of an isolate of a natural pathogen to infect a host species (not possessing major resistance genes) or susceptible genotype to a higher degree than other isolates was evaluated on leaflets of the aforementioned susceptible cultivars of both hosts using the modified 1-9 Disease Severity scale as described by Zarzycka (2001) (see below).

Inocula of the isolates consisted of a sporangial suspension prepared from sporulating lesions adjusted (with a haemocytometer) to a concentration of $5 \times 10^{4}$ sporangia $\mathrm{ml}^{-1}$. After $2 \mathrm{~h}$ of conditioning at $7{ }^{\circ} \mathrm{C}$, two $30-\mu l$ drops of inoculum were placed on the abaxial side of each leaflet. Glass-covered boxes were placed in a cool, illuminated chamber $\left(16^{\circ} \mathrm{C}, 2100 \mathrm{~lx}\right)$. After $24 \mathrm{~h}$, the leaflets were inverted.

Virulence of the isolates was evaluated 7 days after inoculation in a binary fashion: present or absent. Avirulent isolates were those that were not sporulated and caused no lesions or lesions with clear edges, and not bigger than the area of the inoculation drop (up to $3 \%$ of leaf area). Virulent isolates were able to sporulate and cause lesions of an area bigger than that of the inoculation drop. Isolates and race complexity were characterized by two indices: $C_{i}$, the mean number of virulence factors per isolate; and $C_{p}$, the mean number of virulence factors by race. These indices were calculated according to the following formulas (Andrivon 1994):

$$
\begin{aligned}
C_{i} & =\sum_{j}\left(p_{j} v_{j}\right), \text { where } j=1 \ldots N_{p} \text { and } \\
C_{p} & =\sum_{j} v_{j} / N_{p}, \text { where } j=1 \ldots N_{p}
\end{aligned}
$$

where $v_{j}$ is the number of virulence genes of the $j$ th race and $p_{j}$ represents the frequency of the phenotype $j$ in the population, and $N_{p}$ the number of races identified among isolates.

Sporulation intensity tested on susceptible cultivars of both hosts was scored 7 days after inoculation on a 0 3 scale, where:

$0=$ no sporulation

$1=$ weak sporulation with rare, sparsely branched sporangiophores $25 / \mathrm{mm}^{2}$

$2=$ medium or abundant sporulation with numerous, branched sporangiophores $100 / \mathrm{mm}^{2}$

$3=$ very abundant sporulation with very numerous, branched sporangiophores $300 / \mathrm{mm}^{2}$

A modified 1-9 Disease Severity scale (Zarzycka 2001) was applied 7 days after inoculation for the visual estimation of the pathogenicity of $\mathrm{T}$ and $\mathrm{P}$ isolates to the set of tomato differentials:

9- no symptoms or little necrosis, no sporulation; 8 - spots covering $3 \%$ of the leaflet area with clear edges, very weak sporulation;

7- spots with washed away edges covering 3.1$10 \%$ of leaflet area, sporulation more abundant;

6- spots with washed away edges covering 10.1$25 \%$ of leaflet area, sporulation abundant;

5- spots covering $25.1-75 \%$ of leaflet area, sporulation abundant;

4- spots covering 75.1-90\% of leaflet area, sporulation abundant;

3- spots covering 90.1-97\% of leaflet area, sporulation abundant;

2- spots covering 97.1-99\% of leaflet area, sporulation very abundant;

1- spot covering the whole leaflet, sporulation very abundant.

\section{Statistical analysis}

To compare frequencies of virulent $\mathrm{P}$ and $\mathrm{T}$ isolates a chi-square test was performed. The analyses of variance were done to reveal host-origin and tester (potato and tomato) differences in isolate aggressiveness (Table 4) and to reveal host-origin and tomato tester differences in disease severity. In both cases, leaflet infection score means of potato and/or tomato leaflets were subjected to two-way analyses of variance. In the case of analyzing tomato testers inoculated with two types of isolates, the 
design had unequal sizes of treatment combinations due to different numbers of tested isolates and some missing combinations. To avoid problems with uncertain statistical inference from the analysis of an incomplete-design study, statistical analysis was done for the complete 2007 data. To find means that are significantly different from each other, Tukey's HSD tests were performed.

It should be noted, that measurements of aggressiveness and pathogenicity were carried out using 1-9 Disease Severity scores, which do not make an interval scale, hence do not fulfill assumptions of ANOVA. However, these values can be considered usable in such statistical parametric analysis since respective mean values of these scores were used in calculations and all statistical inferences concern those mean values exclusively, without reference to actual values of infection. All tests and analyses were done in Statistical Analysis System $\left(\right.$ SAS $^{\circledR}$ version 9.2, 2009).

\section{Results}

Virulence

\section{Potato differentials}

All of the 76 P. infestans isolates collected from potatoes (P) were virulent to the Black's differentials R1, R3, R4, R7, R10 and R11. Frequency of virulent $P$ isolates to the differentials R2, R5, R6, R8 and cv. Bzura was higher than the frequency of avirulent ones. The frequency of virulent isolates was very low for the R9 differential only (Table 1).

The virulence observed on potato differentials for most of the 100 tomato-derived P. infestans $(\mathrm{T})$ isolates (trans-host species inoculations) differed from that observed for the potato-derived P. infestans (P) isolates (cis-host species inoculations). Almost all $\mathrm{T}$ isolates similarly to $\mathrm{P}$ isolates were able to infect Black's differentials R3, R4, and R7 in duplicate tests. However, differentials R1, R10 and R11 were infected significantly less frequently by $\mathrm{T}$ isolates than by $\mathrm{P}$ isolates $(p<.0001)$. Virulent $\mathrm{T}$ isolates were also significantly less frequent than $\mathrm{P}$ isolates to the remaining differentials R2, R5, R6, R8, R9 and cv. Bzura. (Table 1).

\section{Tomato differentials}

As reported in Table 2, all 176 tested isolates, independent of their origin, were virulent to susceptible cv.
Moneymaker, as well as to cv. New Yorker $(P h-1)$ and S. pimpinellifolium L 3708 (Ph-3). The mean frequencies of $\mathrm{P}$ isolates virulent to West Virginia'63 $(P h-2)$, West Virginia $700(P h-1, P h-2)$, and Ottawa 30 ( $P h-1$, $P h$-2) were relatively high (range 0.59-0.83), but lower than those of virulent $\mathrm{T}$ isolates to these differentials (range 0.85-0.95) and this difference was statistically significant for West Virginia'63 and West Virginia 700 (Table 2). The tester BALU 30 ( $P h-1, P h-2$, and fruit resistance) was used for virulence testing in 2007 only, and the frequencies of virulent $\mathrm{P}$ and $\mathrm{T}$ isolates to BALU 30 were 0.63 and 0.75 , respectively.

\section{Race structure}

Complexity of $P$. infestans races was evaluated on the set of Black's potato differentials. Among 44 races identified from all 176 tested isolates, 30 were found among $\mathrm{T}$ isolates only, two among $\mathrm{P}$ isolates only, and 12 in both groups of isolates. As summarized in Table 3 , $\mathrm{P}$ isolates had a higher mean number of virulence factors, $C_{i}$, and a higher mean number of virulence factors per race, $C_{p}$, than $\mathrm{T}$ isolates, indicating that the former were more complex than the latter. The range of complexity of $\mathrm{P}$ and $\mathrm{T}$ isolates was $6-11$ and 2-11 virulence factors per race, respectively. The most frequent $P$ races were those with 10 or 9 virulence factors: 1.2.3.4.5.6.7.8.10.11 (16 isolates), 1.2.3.4.5.6.7.10.11 (16 isolates), and 1.2.3.4.5.7.8.10.11 (10 isolates). The most frequent $\mathrm{T}$ races were 1.3.4.7 (12 isolates) and 1.3.4.7.8.10.11 (10 isolates). The complexity of $P$. infestans races collected from potato was similar in 3 years of testing. On the contrary, in 2007, more than half of the $\mathrm{T}$ isolates $(29 / 53)$ represented simpler races with fewer virulence factors $(\leq 5)$ than in 2005 and 2006 (Table 3). Of 37 isolates found in 2007 in tomato fields that were located far from potato production, 22 had simple virulence, with 2-5 virulence factors.

Aggressiveness and sporulation intensity

As shown in Table 4, aggressiveness to potato leaflets of $\mathrm{P}$ isolates collected over 3 years was significantly higher than that of $\mathrm{T}$ isolates. Conversely, the tomato-derived isolates were more aggressive than $\mathrm{P}$ isolates on susceptible tomato cv. Moneymaker. This tendency was observed in 3 years of testing, however there was some variation in the aggressiveness of the isolates (Table 4). 
Table 1 Frequency of virulence of $P$. infestans isolates collected from potato versus tomato in 2005-2007 on Black's differentials and potato cv. Bzura

\begin{tabular}{|c|c|c|c|c|c|c|c|c|c|c|c|c|c|}
\hline \multicolumn{2}{|c|}{ Source and number of isolates } & \multicolumn{11}{|c|}{ Black's differentials } & \multirow[t]{2}{*}{ cv. Bzura } \\
\hline & & R1 & $\mathrm{R} 2$ & $\mathrm{R} 3$ & $\mathrm{R} 4$ & R5 & R6 & R7 & $\mathrm{R} 8$ & R9 & $\mathrm{R} 10$ & $\mathrm{R} 11$ & \\
\hline $\mathrm{P}$ & 76 & 1.00 & 0.58 & 1.00 & 1.00 & 0.81 & 0.67 & 1.00 & 0.60 & 0.17 & 1.00 & 1.00 & 0.64 \\
\hline $\mathrm{T}$ & 100 & 0.81 & 0.26 & 0.99 & 0.99 & 0.20 & 0.26 & 0.99 & 0.31 & 0.04 & 0.59 & 0.66 & 0.19 \\
\hline \multicolumn{2}{|l|}{$P$ values } & $* * *$ & $* *$ & na & na & $* * *$ & $* * *$ & na & $* *$ & $* *$ & $* * *$ & $* * *$ & $* * *$ \\
\hline
\end{tabular}

Isolates were multiplied on leaflets from their respective hosts and evaluated in duplicate tests

na not applicable

$P$ values for significance of difference between distributions of virulent $\mathrm{P}$ and $\mathrm{T}$ isolates

$* * \mathrm{P}<0.01$

$* * * \mathrm{P}<0.001$

The most intensive sporulation of 76 potato-derived $P$. infestans isolates tested over 3 years was observed on the potato leaflets (Table 4). P isolates expressed a lower intensity of sporulation on tomato leaflets than on potato leaflets. In turn, the sporulation intensities of $\mathrm{T}$ isolates were similar on susceptible potato and tomato leaflets, with the highest frequencies of isolates being class 3 in both cases (Table 4).
Pathogenicity of $\mathrm{P}$ and $\mathrm{T}$ isolates to tomato differentials in 2007

In 2007, the pathogenicity of $35 \mathrm{P}$ and $53 \mathrm{~T}$ isolates was evaluated on seven tomato differentials, representing donors of various $P$. infestans resistance genes. The $\mathrm{cv}$. Moneymaker and five tomato differentials were significantly more infected by $\mathrm{T}$ isolates than by $\mathrm{P}$ isolates ( $\mathrm{p}$

Table 2 Frequency of virulence of $P$. infestans isolates collected from potato versus tomato in 2005-2007 on tomato testers by year of collection

\begin{tabular}{|c|c|c|c|c|c|c|c|c|c|}
\hline \multirow{2}{*}{$\begin{array}{l}\text { Year of } \\
\text { collection }\end{array}$} & & \multirow{2}{*}{$\begin{array}{l}\text { Source and } \\
\text { number of } \\
\text { isolates }\end{array}$} & \multicolumn{7}{|c|}{ Tomato resistance testers } \\
\hline & & & $\begin{array}{l}\text { cv. } \\
\text { Moneymaker } \\
(p h)\end{array}$ & $\begin{array}{l}\text { cv. New } \\
\text { Yorker }(P h-l)\end{array}$ & $\begin{array}{l}\text { S.p. } 3708^{\text {a }} \\
(P h-3)\end{array}$ & $\begin{array}{l}\text { WV'63 b } \\
(P h-2)\end{array}$ & $\begin{array}{l}\text { WV } 700^{\mathrm{c}} \\
(P h-1, P h-2)\end{array}$ & $\begin{array}{l}\text { Ottawa } 30 \\
(P h-1, P h-2)\end{array}$ & $\begin{array}{l}\text { BALU-30 }(P h- \\
1, P h-2,(f)\end{array}$ \\
\hline \multirow[t]{2}{*}{2005} & $\mathrm{P}$ & 24 & 1.00 & 1.00 & 1.00 & 0.21 & 0.08 & $\mathrm{nt}$ & $\mathrm{nt}$ \\
\hline & $\mathrm{T}$ & 24 & 1.00 & 1.00 & 1.00 & 0.67 & 0.54 & $\mathrm{nt}$ & $\mathrm{nt}$ \\
\hline \multirow[t]{2}{*}{2006} & $\mathrm{P}$ & 17 & 1.00 & 1.00 & 1.00 & 1.00 & 0.76 & 0.88 & $\mathrm{nt}$ \\
\hline & $\mathrm{T}$ & 23 & 1.00 & 1.00 & 1.00 & 1.00 & 1.00 & 1.00 & $\mathrm{nt}$ \\
\hline \multirow[t]{2}{*}{2007} & $\mathrm{P}$ & 35 & 1.00 & 1.00 & 1.00 & 0.94 & 0.89 & 0.80 & 0.63 \\
\hline & $\mathrm{T}$ & 53 & 1.00 & 1.00 & 1.00 & 0.96 & 0.92 & 0.92 & 0.75 \\
\hline \multirow{2}{*}{$\begin{array}{l}\text { Overall } \\
\text { frequen- } \\
\text { cy }\end{array}$} & $\mathrm{P}$ & & 1.00 & 1.00 & 1.00 & 0.62 & 0.59 & 0.83 & 0.63 \\
\hline & $\mathrm{T}$ & & 1.00 & 1.00 & 1.00 & 0.86 & 0.85 & 0.95 & 0.75 \\
\hline$P$ values & & & na & na & na & $* * *$ & $* * *$ & ns & ns \\
\hline
\end{tabular}

Tests were conducted in duplicate

$n s$ not significant; $n a$ not applicable; $n t$ not tested

$P$ values for significance of difference between distributions of virulent $\mathrm{P}$ and $\mathrm{T}$ isolates

$* * * \mathrm{P}<0.001$

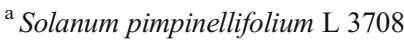

b West Virginia'63

${ }^{\mathrm{c}}$ West Virginia 700 
Table 3 Races of $P$. infestans collected from potato (P) and tomato (T) in 2005-2007 in Poland

\begin{tabular}{|c|c|c|c|c|c|c|c|c|c|}
\hline \multirow[t]{3}{*}{ Number of virulence factors } & \multirow[t]{3}{*}{ Races } & \multicolumn{6}{|c|}{ Number of isolates collected from } & \multicolumn{2}{|c|}{ Total number of isolates } \\
\hline & & \multicolumn{3}{|c|}{ potato in } & \multicolumn{3}{|c|}{ tomato in } & \multirow[b]{2}{*}{$\mathrm{P}$} & \multirow[b]{2}{*}{$\mathrm{T}$} \\
\hline & & 2005 & 2006 & 2007 & 2005 & 2006 & 2007 & & \\
\hline 2 & 1.4 & - & - & - & - & - & 1 & - & 1 \\
\hline 3 & 3.4 .7 & - & - & - & - & - & 6 & - & 6 \\
\hline \multirow[t]{3}{*}{4} & 1.3.4.7 & - & - & - & 3 & - & 9 & - & 12 \\
\hline & 3.4 .7 .10 & - & - & - & - & - & 1 & - & 1 \\
\hline & 3.4.7.11 & - & - & - & - & - & 3 & - & 3 \\
\hline \multirow[t]{7}{*}{5} & 1.2 .3 .4 .7 & - & - & - & - & - & 3 & - & 3 \\
\hline & 1.3.4.7.8 & - & - & - & - & - & 1 & - & 1 \\
\hline & 1.3.4.7.10 & - & - & - & - & - & 1 & - & 1 \\
\hline & 1.3 .4 .7 .11 & - & - & - & - & 1 & 1 & - & 2 \\
\hline & 2.3 .4 .7 .10 & - & - & - & - & - & 1 & - & 1 \\
\hline & 2.3.4.7.11 & - & - & - & - & 1 & - & - & 1 \\
\hline & 3.4.7.10.11 & - & - & - & - & 1 & 2 & - & 3 \\
\hline \multirow[t]{12}{*}{6} & 1.2 .3 .4 .5 .7 & - & - & - & - & - & 1 & - & 1 \\
\hline & 1.3.4.6.7.11 & - & - & - & - & - & 1 & - & 1 \\
\hline & 1.2.3.4.6.7 & - & - & - & - & - & 4 & - & 4 \\
\hline & 1.2.3.4.7.11 & - & - & - & - & - & 1 & - & 1 \\
\hline & 1.2 .3 .6 .7 .11 & - & - & - & - & - & 1 & - & 1 \\
\hline & 1.3.4.6.7.11 & - & - & - & - & - & 1 & - & 1 \\
\hline & 1.3.4.7.8.10 & - & - & - & - & - & 1 & - & 1 \\
\hline & 1.3 .4 .7 .8 .11 & - & - & - & 2 & 1 & - & - & 3 \\
\hline & 1.3.4.7.10.11 & 1 & - & 4 & 3 & - & 3 & 5 & 6 \\
\hline & 2.3 .4 .5 .7 .10 & - & - & - & - & - & 1 & - & 1 \\
\hline & 2.3 .4 .7 .10 .11 & - & - & - & - & - & 1 & - & 1 \\
\hline & 3.4.7.8.10.11 & - & - & - & - & - & 1 & - & 1 \\
\hline \multirow[t]{5}{*}{7} & 1.2 .3 .4 .7 .10 .11 & - & - & - & - & - & 1 & - & 1 \\
\hline & 1.3 .4 .5 .7 .10 .11 & 1 & - & 3 & - & 1 & 3 & 4 & 4 \\
\hline & 1.3 .4 .6 .7 .10 .11 & - & - & - & - & 6 & - & - & 6 \\
\hline & 1.3 .4 .7 .8 .10 .11 & 1 & - & - & 3 & - & 1 & 1 & 4 \\
\hline & 1.3 .4 .7 .8 .10 .11 & 6 & - & 1 & 8 & 2 & - & 7 & 10 \\
\hline \multirow[t]{5}{*}{8} & $1.2 .3 \cdot 4 \cdot 5 \cdot 6.7 .11$ & - & - & - & - & 1 & - & - & 1 \\
\hline & 1.2.3.4.7.8.10.11 & - & - & - & 1 & 1 & - & - & 2 \\
\hline & 1.3.4.5.7.8.10.11 & 4 & 2 & 4 & 2 & - & 2 & 10 & 4 \\
\hline & 1.3.4.5.6.7.10.11 & - & 3 & - & - & 1 & - & 3 & 1 \\
\hline & 2.3.4.6.7.8.10.11 & - & - & - & - & - & 1 & - & 1 \\
\hline \multirow[t]{4}{*}{9} & 1.2 .3 .4 .5 .6 .7 .10 .11 & 2 & 6 & 8 & - & 2 & - & 16 & 2 \\
\hline & $1.2 .3 .4 \cdot 6.7 .8 .10 .11$ & 2 & - & - & 1 & 1 & - & 2 & 2 \\
\hline & 1.3 .4 .5 .6 .7 .8 .10 .11 & - & 1 & - & - & - & - & 1 & - \\
\hline & 1.3.4.5.6.7.9.10.11 & - & 3 & - & - & - & - & 3 & - \\
\hline \multirow[t]{3}{*}{10} & $1.2 .3 .4 \cdot 5 \cdot 6.7 .8 \cdot 10.11$ & 5 & 1 & 10 & - & 1 & - & 16 & 1 \\
\hline & $1.2 .3 .4 .5 \cdot 6.7 .9 .10 .11$ & - & - & 1 & - & 1 & - & 1 & 1 \\
\hline & 1.3.4.5.6.7.8.9.10.11 & - & - & - & - & 2 & - & - & 2 \\
\hline
\end{tabular}


Table 3 (continued)

\begin{tabular}{|c|c|c|c|c|c|c|c|c|c|}
\hline \multirow[t]{3}{*}{ Number of virulence factors } & \multirow[t]{3}{*}{ Races } & \multicolumn{6}{|c|}{ Number of isolates collected from } & \multirow{2}{*}{\multicolumn{2}{|c|}{ Total number of isolates }} \\
\hline & & \multicolumn{3}{|c|}{ potato in } & \multicolumn{3}{|c|}{ tomato in } & & \\
\hline & & 2005 & 2006 & 2007 & 2005 & 2006 & 2007 & $\mathrm{P}$ & $\mathrm{T}$ \\
\hline 11 & 1.2.3.4.5.6.7.8.9.10.11 & 2 & 1 & 4 & 1 & - & - & 7 & 1 \\
\hline \multicolumn{2}{|l|}{ Total number } & 24 & 17 & 35 & 24 & 23 & 53 & 76 & 100 \\
\hline \multicolumn{2}{|c|}{ Mean number of virulence factors per race $C_{p}$} & 8.22 & 9.14 & 8.50 & 7.33 & 7.60 & 5.56 & 8.46 & 6.45 \\
\hline \multicolumn{2}{|c|}{ Mean number of virulence factors per isolate $C_{i}$} & 8.42 & 8.89 & 8.86 & 6.79 & 7.61 & 5.13 & 8.72 & 6.10 \\
\hline
\end{tabular}

$<.01$ ), with lower scores signifying stronger severity of the disease development. The exception was West Virginia 700, which was affected similarly by $\mathrm{P}$ and $\mathrm{T}$ isolates (Fig. 1). The cultivars Moneymaker, New Yorker, and S. pimpinellifolium L 3708 belong to a homogeneous group that was in general more susceptible to infection with isolates of both origins than were other tomato differentials. The intermediate disease severity group consisted of cv. West Virginia'63, the West Virginia 700 and Ottawa 30 accessions. As compared to the latter group, the BALU 30 line expressed significantly lower disease severity with $\mathrm{P}$ isolates (7.79), but a statistically similar score with $\mathrm{T}$ isolates (Fig. 1). Representative examples of reciprocal $P$. infestans infection of potato and tomato differentials with $\mathrm{T}$ and $\mathrm{P}$ isolates are shown in Fig. 2.

Table 4 Aggressiveness and sporulation of $P$. infestans isolates obtained from potato (P) and tomato (T) in 2005-2007 on susceptible potato and tomato testers

\begin{tabular}{|c|c|c|c|c|c|c|c|c|}
\hline \multirow[t]{2}{*}{ Year } & \multicolumn{2}{|c|}{$\begin{array}{l}\text { Source and number of } \\
\text { isolates }\end{array}$} & \multirow[t]{2}{*}{ Tester genotype ${ }^{a}$} & \multirow[t]{2}{*}{ Aggressiveness in 1-9 scale ${ }^{b}$} & \multicolumn{4}{|c|}{$\begin{array}{l}\text { Frequency of isolates in sporulation } \\
\text { classes }\end{array}$} \\
\hline & & & & & 0 & 1 & 2 & 3 \\
\hline \multirow[t]{4}{*}{2005} & \multirow[t]{2}{*}{$\mathrm{P}$} & \multirow[t]{2}{*}{24} & $r$ & 2.40 & 0.00 & 0.00 & 0.05 & 0.95 \\
\hline & & & $p h$ & 5.25 & 0.02 & 0.15 & 0.79 & 0.04 \\
\hline & \multirow[t]{2}{*}{$\mathrm{T}$} & \multirow[t]{2}{*}{24} & $r$ & 2.55 & 0.02 & 0.00 & 0.13 & 0.85 \\
\hline & & & $p h$ & 3.50 & 0.00 & 0.00 & 0.19 & 0.81 \\
\hline \multirow[t]{4}{*}{2006} & \multirow[t]{2}{*}{$\mathrm{P}$} & \multirow[t]{2}{*}{17} & $r$ & 1.55 & 0.00 & 0.00 & 0.00 & 1.00 \\
\hline & & & $p h$ & 4.92 & 0.03 & 0.21 & 0.55 & 0.21 \\
\hline & \multirow[t]{2}{*}{$\mathrm{T}$} & \multirow[t]{2}{*}{23} & $r$ & 1.45 & 0.00 & 0.00 & 0.04 & 0.96 \\
\hline & & & $p h$ & 2.00 & 0.00 & 0.00 & 0.02 & 0.98 \\
\hline \multirow[t]{4}{*}{2007} & \multirow[t]{2}{*}{$\mathrm{P}$} & \multirow[t]{2}{*}{35} & $r$ & 1.40 & 0.01 & 0.00 & 0.01 & 0.98 \\
\hline & & & $p h$ & 4.54 & 0.00 & 0.06 & 0.78 & 0.16 \\
\hline & \multirow[t]{2}{*}{$\mathrm{T}$} & \multirow[t]{2}{*}{53} & $r$ & 2.70 & 0.09 & 0.02 & 0.08 & 0.81 \\
\hline & & & $p h$ & 2.91 & 0.02 & 0.01 & 0.10 & 0.87 \\
\hline \multirow[t]{4}{*}{ Total / weighted mean } & \multirow[t]{2}{*}{$\mathrm{P}$} & \multirow[t]{2}{*}{76} & $r$ & $1.75 \mathrm{a}^{\#}$ & 0.00 & 0.00 & 0.01 & 0.99 \\
\hline & & & $p h$ & $4.85 \mathrm{~d}$ & 0.01 & 0.12 & 0.74 & 0.13 \\
\hline & \multirow[t]{2}{*}{$\mathrm{T}$} & \multirow[t]{2}{*}{100} & $r$ & $2.38 \mathrm{~b}$ & 0.07 & 0.01 & 0.08 & 0.84 \\
\hline & & & $p h$ & $2.84 \mathrm{c}$ & 0.01 & 0.00 & 0.11 & 0.88 \\
\hline
\end{tabular}

${ }^{a} r$ potato cvs Craigs Royal, Tarpan, Bintje; $p h$, tomato cv. Moneymaker

${ }^{\mathrm{b}} 1-9$ scale, where $1=99-100 \%$ of leaflet area infected (most aggressive) and $9=$ no symptoms of infection or little necrosis (Zarzycka 2001)

${ }^{\mathrm{c}} 0-3$ classes, where $0=$ no sporulation and $3=$ very abundant sporulation

\# homogenous groups based on Tukey's test 


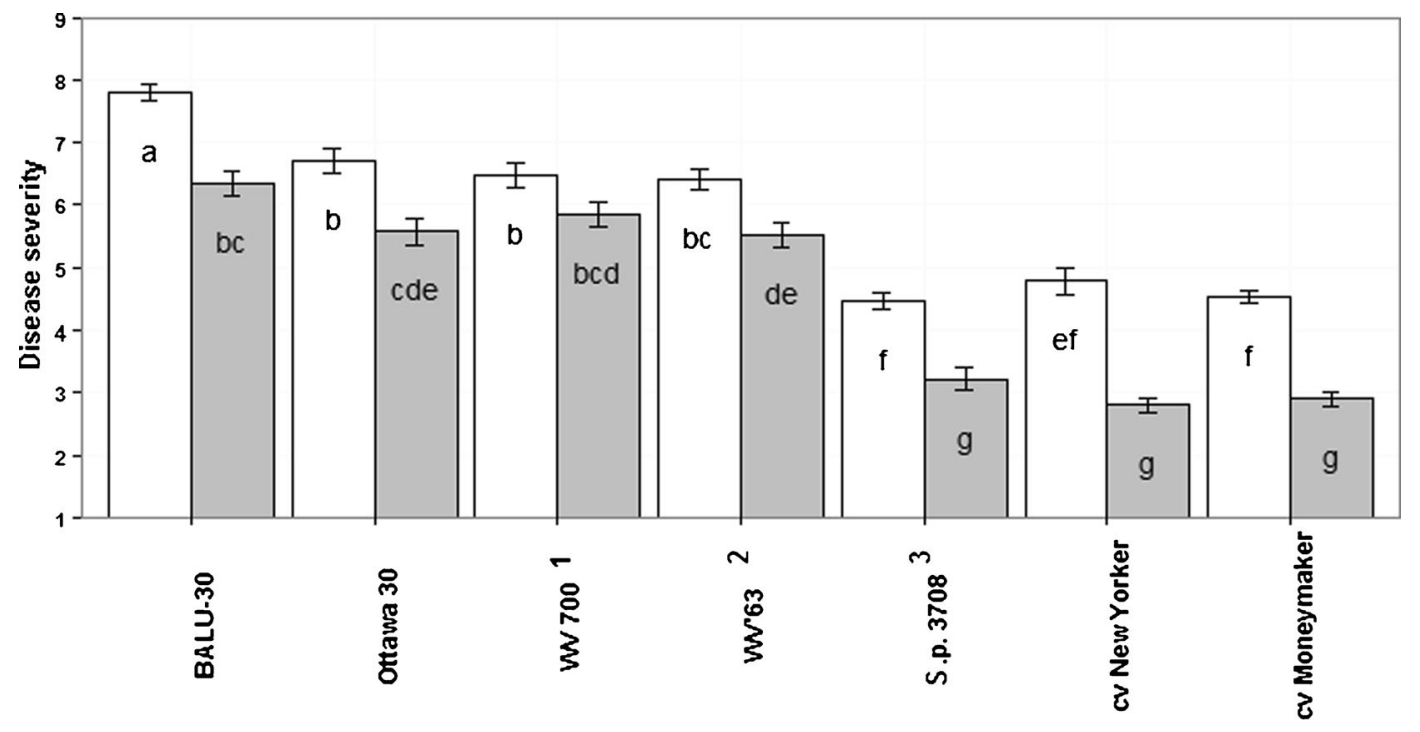

potato isolate $\square$ tomato isolate

Fig 1 Disease Severity scores for $\mathrm{P}(n=35)$ and $\mathrm{T}(n=53)$ isolates obtained in 2007 on tomato leaflets from seven testers varying in resistance to $P$. infestans. Disease Severity was scored on a 1-9 scale (Zarzycka 2001), where 1 indicates the complete infection
$(100 \%)$. Mean scores are shown with standard errors of the mean. Mean values with the same letter do not differ significantly (Tukey HSD value $=0.87) .{ }^{1}$ West Virginia $700 ;{ }^{2}$ West Virginia'63; ${ }^{3}$ Solanum pimpinellifolium L 3708

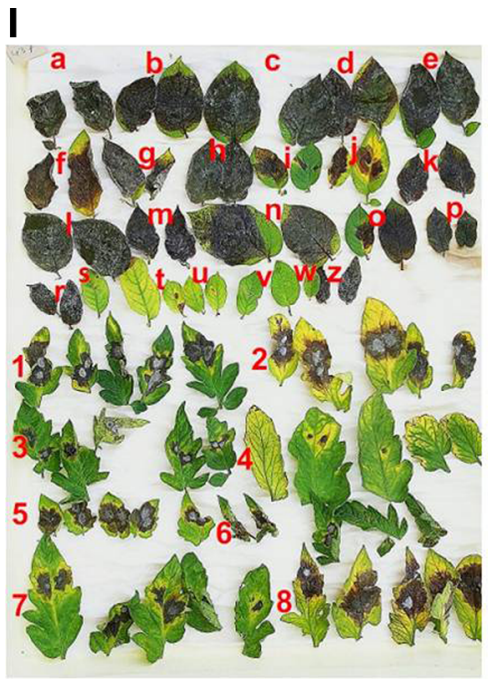

Fig 2 Representative pictures of tester potato and tomato leaflets. These photographs were taken 7 days after infection with P. infestans: I. P isolate MP 865 collected in Młochów from potato cv. Vineta, and II. T isolate no. 433/07 collected in Jadwisin from fruit of susceptible tomato. Two leaflets from each potato tester are shown from left to right as follows: a, cv. Tarpan $(r)$; b, R1; c, R2; d,
II

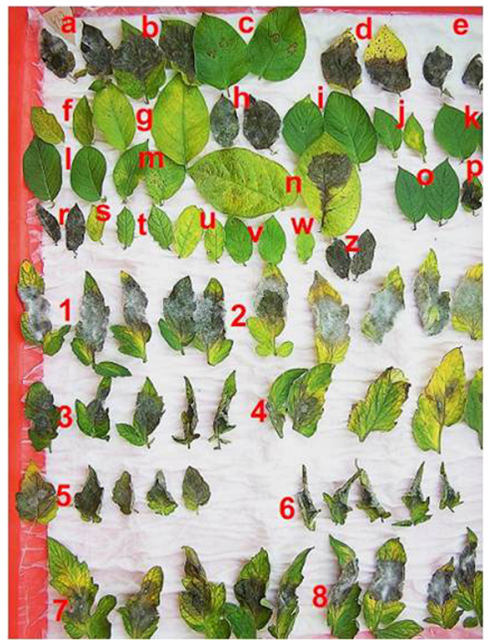

R3; e, R4; f, R5; g, R6; h, R7; i, R8; j, R9; k, R10; 1, R11; m, cv. Bzura; $\mathrm{n}-\mathrm{z}$, forms not mentioned in the text. Five leaflets from each tomato tester are shown as follows: $1, \mathrm{cv}$. Moneymaker $(p h) ; 2$, cv. New Yorker; 3, Ottawa 30; 4, BALU 30; 5, S. pimpinellifolium L 3708; 6, West Virginia 700; 7, West Virginia'63; and 8, cv. Lubań (ph) 


\section{Discussion}

The present study was focused on detection of host adaptation in isolates originating from potato and tomato plants. A key aspect of our experiment was that the collected isolates (76 P and $100 \mathrm{~T}$ ) were maintained on their respective host plants to protect their potential adaptive characteristics. In most other studies, $P$. infestans isolates have been maintained on agar medium, although some have conducted multiplication of isolates on potato tissue (Andrivon et al. 1994; Legard et al. 1995; Forbes et al. 1997; Lebreton and Andrivon 1998; Dorrance et al. 1999; Lebreton et al. 1999; Vega-Sánchez et al. 2000). The loss of pathogenicity of isolates during long-term culturing on agar has been noted by some authors (Wilson and Gallegly 1955; Jinks and Grindle 1963). Zarzycka $(1995,1996)$ noticed a significant decrease in aggressiveness and virulence of $P$. infestans isolates maintained on rye agar, whereas isolates maintained on potato leaflets were more aggressive and had a wider virulence spectrum, with less variability of both characteristics. Thus, it appears that the method of isolate multiplication adopted before testing might influence experimental results.

The $\mathrm{P}$ isolates in this study were virulent to 10 potato differentials and cv. Bzura, but not to the R9 differential. The virulence spectra of isolates recently collected from potato in Poland (Śliwka et al. 2006; Chmielarz et al. 2014) were similar to our results. The frequencies of $P$ isolates that were virulent against respective R-genes in our study were higher than those reported by Andrivon et al. (1994), Świeżyński et al. (2000), Knapova and Gisi (2002), and Blandón-Diaz et al. (2012). On the whole, the $\mathrm{P}$ isolates tested in this study showed $100 \%$ of virulent forms against R1, R3, R4, R7, R10, and R11 and frequent presence of virulence against R5, R6, and R8 differentials. Meanwhile, virulence spectrum data for 4584 European isolates sampled for two decades (1992-2012) as part of the Eucablight project (www.eucablight.org) and for 743 isolates sampled in 2003 in four Nordic countries (Lehtinen et al. 2008) showed similar tendencies to our data.

We found that $\mathrm{T}$ isolates had fewer virulence factors against potato differentials than had $\mathrm{P}$ isolates, as reflected by the frequency of virulent isolates. This finding is in agreement with prior studies by Lebreton and Andrivon (1998), Oyarzun et al. (1998), Knapova and Gisi (2002), and Blandón-Diaz et al. (2012), and indicates lower host specificity of $\mathrm{T}$ isolates than $\mathrm{P}$ isolates to a potato host. Cohen (2002) found that $\mathrm{P}$ and $\mathrm{T}$ isolates collected in Israel between 1998 and 2000, when heavy epidemics of late blight occurred in tomato, had similar complex virulence spectra with unexpectedly high frequencies of the factor against the R9 gene and low frequency of the factor corresponding with R2. Cohen concluded that $\mathrm{T}$ isolates were locally evolved from the $\mathrm{P}$ population and acquired specialization to tomato.

The complexity of $P$. infestans races and isolates was described by the $C_{p}$ and $C_{i}$ indices, respectively, in our study. Both indices were higher for $\mathrm{P}$ isolates than for $\mathrm{T}$ isolates, confirming higher complexity for $\mathrm{P}$ isolates. Indeed, greater complexity of $\mathrm{P}$ isolates and more pathotypes of Polish $P$. infestans were observed than has been observed for populations from four Nordic countries (Lehtinen et al. 2008), a Nicaraguan population (Blandón-Diaz 2011), and a Peruvian population (with the exception of 5 isolates from Huanuco; Perez et al. 2001). Note that Polish $P$ isolates had a higher value of $C_{i}$ than $C_{p}$, indicating that the most complex races were predominant among the most common pathotypes. Similarly to other studies in the literature, rare virulence factors (e.g., against R9) in highly complex pathotypes were observed (Andrivon 1994; Andrivon et al. 1994; Lehtinen et al. 2008). The pronounced presence of highly complex pathotypes in a recent potato-infecting $P$. infestans population could be the result of sexual reproduction of the pathogen in Poland (Chmielarz et al. 2014).

Relative to $\mathrm{P}$ isolates, we found that $\mathrm{T}$ isolates were more variable and had an enhanced presence of relatively simple $P$. infestans races (with four virulence factors) as well as slightly more representation of races with sevenfactor complexity. The $C_{i}$ index was lower than the $C_{p}$ index in $\mathrm{T}$ isolates, confirming a relatively simpler virulence structure of the most common tomato-derived pathotypes. Similar simpler virulence structure of $\mathrm{T}$ isolates than $\mathrm{P}$ isolates collected in France and Switzerland in 1996-1997 was found by Knapova and Gisi (2002). In 2007, a group of $22 \mathrm{~T}$ isolates with low numbers of virulence factors (from 2 to 5 ) was collected from tomato fields located far from any potato fields. As discussed by Lebreton and Andrivon (1998) and Lebreton et al. (1999), the occurrence of simpler $\mathrm{T}$ isolates may be the result of a loss of adaptability to a potato host. Interestingly, the simple virulence spectrum of this group of isolates on potato testers was not associated with lower aggressiveness or a more narrow virulence spectrum on tomato testers. 
A relatively small number of studies have examined the virulence spectrum of both $\mathrm{P}$ and $\mathrm{T}$ isolates on tomato plants, in which resistance comes from various sources (Chen et al. 2008). Our set of tomato testers was composed of six genotypes with diverse known tomato resistance genes (e.g., $P h 1, P h 2, P h 3$, and fruit resistance with an undefined genetic background). Surprisingly, the virulence of $\mathrm{P}$ and $\mathrm{T}$ isolates on testers with $P h-1$ and $P h-3$ genes was similar; that is, all 176 isolates tested were virulent towards plants with both genes. The resistance governed by $P h-1$ has been present in tomato cultivars bred since the 1960s. According to Fry (2008), this resistance was overcome by a new population of P. infestans in the 1980s and 1990s. The cv. New Yorker is a flagship example of this resistance conquest (Nowicki et al. 2013). The gene $P h-3$ has been described as highly effective against a wide range of $P$. infestans isolates and has been explored in tomato breeding (AVRDC 1993; Foolad et al. 2008; Chunwongse et al. 2002; Nowicki et al. 2013). In Taiwan, Chen et al. (2008) found that only 34 tomato isolates (races T1 or $\mathrm{T} 1,2$ ) of 177 tested were avirulent to seedlings of the differential with the $P h-3$ gene. However, substantial infection of $P h-3$ carrying hosts in detached leaflets may reflect a higher sensitivity of leaflets of this genotype than the whole seedlings. Resistance expression of this genotype is age sensitive as discussed by Nowakowska et al. (2014). In the present study, virulence frequencies were higher among virulent $\mathrm{T}$ isolates than $\mathrm{P}$ isolates for tomato differentials that include $P h-2$, namely West Virginia'63 (Ph-2), West Virginia $700(P h-$ 1, $P h-2)$, Ottawa 30 (Ph-1, Ph-2), and BALU-30 (Ph-1, $P h-2$, and fruit resistance). Thus, the frequencies of virulence factors in reciprocal testing indicate that there has been some adaptation of both potato and tomatoderived populations of $P$. infestans to their respective hosts.

We obtained additional evidence of adaptation in the isolates pathogenicity observed on six tomato differentials and cv. Moneymayker infected with $53 \mathrm{~T}$ and $35 \mathrm{P}$ isolates from 2007. The cv. New Yorker and line S. pimpinellifolium L 3708 were the most severely infected. The forms with the $P h-2$ gene were less prone to infection, with the weakest infection being observed for BALU-30. However, in each of these cases, $P$ isolates induced significantly lower disease severity on tomato differentials than did $\mathrm{T}$ isolates. Similarly, Lebreton et al. (1999) and Knapova and Gisi (2002) found that lesions induced on tomato leaves by $\mathrm{P}$ isolates spread much more slowly than lesions caused by $\mathrm{T}$ isolates. Hence, similar pathogenic tendencies were observed for $\mathrm{P}$ and $\mathrm{T}$ isolates on tomato testers, but disease severity was stronger for the $\mathrm{T}$ isolates, indicating that they were better adapted to infect tomato tissue.

Our findings indicate that BALU-30 (selected by A.M. Michalska) may be an effective source of lateblight resistance for tomato plants in Poland. BALU-30 originated from a cross of Ottawa 30 with the line BA, which served as a donor of fruit resistance (Bednara et al. 1996). Line BA was produced by a cross between the cv. The Amateur and the line Beaverlodge 6703 (obtained by R. E. Haris at the Agriculture Canada Research Station, Beaverlodge, Canada).

In our reciprocal testing, all of the studied isolates were pathogenic to both hosts and all were more aggressive on potato than tomato, which was consistent with prior studies by Knapova and Gisi (2002) and Vega-Sánchez et al. (2000). Similarly to Knapova and Gisi (2002), we also found that $P$ isolates had greater sporulation intensity on potato hosts, with that on tomato hosts being one grade lower, whereas Tisolate sporulation intensities were similar (high) with both hosts. These findings support the conclusion that potato tissue is a better host than tomato tissue for P. infestans, as exemplified in Fig. 2.

Aggressiveness and sporulation intensity findings for isolates from different hosts have been contradictory in the literature. For example, Blandón-Diaz et al. (2012) found that $\mathrm{P}$ and $\mathrm{T}$ isolates collected in Nicaragua were more aggressive on tomato leaflets than on potato leaflets. Legard et al. (1995) identified among P isolates tomato-nonaggressive and tomato-aggressive isolates, with the latter causing severe disease on both hosts, though more severely on tomato. In laboratory experiments, Lebreton et al. (1999) found weaker sporulation of $\mathrm{T}$ isolates on potato leaflets than of $\mathrm{P}$ isolates. Interestingly, Lee et al. (2002) have suggested that lower aggressiveness of $P$. infestans isolates to tomato may be modulated by a mutation in a single locus, with low aggressiveness to tomato being the dominant phenotype for that locus. This hypothesis posits that high aggressiveness toward tomato may have evolved independently via mutations in various pathogen genotypes in different locations in the world.

In conclusion, although we did not find evidence of extreme host specialization in the present study, we did find that the virulence spectra of the $\mathrm{P}$ and $\mathrm{T}$ isolates, their race structures, and the weaker sporulation 
intensity of $\mathrm{P}$ isolates on tomato supported the notion that the $P$. infestans isolates had adapted to some extent to their host of origin. On the other hand, the stronger aggressiveness of all isolates on potato compared to tomato hosts and the similar sporulation intensities of $\mathrm{T}$ isolates on both hosts suggest that potato is a better suited host than tomato for $P$. infestans infection and development. The present evidence in support of host adaptation was not conditioned by an ability to cause disease, but rather by quantitative differences in pathogenic fitness (Vega-Sánchez et al. 2000). Genetic characterization of representative samples of $\mathrm{P}$ and $\mathrm{T}$ populations is needed to place the present findings in a fuller context.

Acknowledgments This work was supported by statutory projects DS 1-3-00-3-06 and DS 1-3-00-7-02 of the Plant Breeding and Acclimatization Institute, Młochów Research Center. We thank Jadwiga Śliwka and Waldemar Marczewski for their critical reviewing of this manuscript.

Open Access This article is distributed under the terms of the Creative Commons Attribution 4.0 International License (http://creativecommons.org/licenses/by/4.0/), which permits unrestricted use, distribution, and reproduction in any medium, provided you give appropriate credit to the original author(s) and the source, provide a link to the Creative Commons license, and indicate if changes were made.

\section{References}

Andrivon, D. (1994). Race structure and dynamics in population of Phytophthora infestans. Canadian Journal of Botany, 72, 1681-1687.

Andrivon, D., Béasse, C., \& Laurent, C. (1994). Characterization of isolates of Phytophthora infestans collected in northwestern France from 1988 to 1992. Plant Pathology, 43, 471478.

AVRDC. (1993). 1993 Progress report (pp. 201-203). Shanhua: Asian Vegetable Research and Development Center.

Bednara, J., Michalska, A. M., \& Pazio, M. (1996). Interaction between surface of tomato fruit and the Fungus Phytophthora infestans. Bulletin of the Polish Academy of Sciences, 44(12), 49-56.

Black, W. (1952). A genetical basis for the classification of strains of Phytophthora infestans. Proceedings of The Royal Society of Edinburgh, B65, 36-51.

Black, L. L., Wang, T. C., Hanson, P. M., \& Huang, Y.-H. (1996). New sources of late blight resistance identified in wild tomatoes. TVIS Newsletter, 1(1), 15-17.

Blandón-Diaz J. U. (2011). Insight into population structure and epidemiology of Phytophthora infestans from Nicaragua. Doctoral Thesis No 2001:36; Faculty of Natural Resources and Agricultural Sciences, SLU, 1-74.
Blandón-Diaz, J. U., Widmark, A.-K., Hannukkala, A., Andersson, B., Högberg, N., \& Yuen, J. E. (2012). Phenotypic variation within a clonal lineage of Phytophthora infestans infecting both tomato and potato in Nicaragua. Phytopathology, 102, 323-330.

Chen, C.-H., Sheu, Z.-M., \& Wang, T.-C. (2008). Host specificity and tomato-related race composition of Phytophthora infestans isolates in Taiwan during 2004 and 2005. Plant Disease, 92, 751-755.

Chmielarz, M., Sobkowiak, S., Dębski, K., Cooke, D. E. L., Brurberg, M. B., \& Śliwka, J. (2014). Diversity of Phytophthora infestans in Poland. Plant Pathology, 63, 203-211.

Chunwongse, J., Chunwongse, L., Black, L., \& Hanson, P. (2002). Molecular mapping of the $\mathrm{Ph}-3$ gene for late blight resistance in tomato. The Journal of Horticultural Science and Biotechnology, 77(3), 281-286.

Cohen, Y. (2002). Populations of Phytophthora infestans in Israel underwent three major genetic changes during 1983 to 2000. Phytopathology, 92, 300-307.

Derie, M. L., \& Inglis, D. A. (2001). Persistence of complex virulences in populations of Phytophthora infestans in Western Washington. Phytopathology, 91, 606-612.

Dorrance, A. E., Inglis, D. A., Derie, M. L., Brown, C. R., Goodwin, S. B., Fry, W. E., et al. (1999). Characterization of Phytophthora infestans populations in western Washington. Plant Disease, 83, 423-428.

Ferguson, W., Layall, L. H., \& Racicot, H. N. (1952). Tomato breeding for resistance to Phytophthora infestans (Mont.) de by. Scientistic Agriculture, 32, 57-66.

Foolad, M. R., Merk, H. L., \& Ashrafi, H. (2008). Genetics, genomics and breeding of late blight and early blight resistance in tomato. Critical Reviews in Plant Sciences, 27, 75107.

Forbes, G. A., Escobar, Z. C., Ayala, C. C., Revelo, J., Ordonez, M. E., Fry, B. A., et al. (1997). Population genetic structure of Phytophthora infestans in Ecuador. Phytopathology, 87, 375-380.

Fry, W. (2008). Phytophthora infestans: the plant (and R gene) destroyer. Molecular Plant Pathology, 9(3), 385-402.

Gallegly, M. E. (1952). Physiologic races of the tomato late blight fungus. Phytopathology, 42, 461-462.

Giddings, N. J., \& Berg, A. (1919). A comparison of the late blights of tomato and potato: A preliminary report. Phytopathology, 9, 209-210b.

Goodwin, S. B., Sujkowski, L. S., \& Fry, W. E. (1995). Rapid evolution of pathogenicity within clonal lineages of the potato late blight disease fungus. Phytopathology, 85, 669-676.

Harbaoui, K., van der Lee, T., Vleeshouwers, V. G. A. A., Khammassy, N., Harrabi, M., \& Hamada, W. (2013). Characterization of Phytophthora infestans isolates collected from potato and tomato crops in Tunisia during 2006-2008. Potato Research, 56(1), 11-29.

Jaime-Garcia, R., Trinidad-Correa, R., Felix-Gastelum, R., Orum, T. V., Wasmann, C. C., \& Nelson, M. N. (2000). Temporal and spatial patterns of genetic structure of Phytophthora infestans from tomato and potato in the Del Fuerte Valley. Phytopathology, 90, 1188-1195.

Jinks, J. L., \& Grindle, M. (1963). Changes induced by training in Phytophthora infestans. Heredity, 18, 245-264. 
Klarfeld, S., Rubin, A. E., \& Cohen, Y. (2009). Pathogenic fitness of oosporic progeny isolates of Phytophthora infestans on late-blight-resistant tomato lines. Plant Disease, 93, 947953.

Knapova, G., \& Gisi, U. (2002). Phenotypic and genotypic structure of Phytophthora infestans populations on potato and tomato in France and Switzerland. Plant Pathology, 51, 641-653.

Laterrot, H. (1975). Selection pour la resistance au mildiou, Phytophthora infestans Mont.; de Bary chez la tomate. Annales de l'Amelioration des Plantes, 25, 129-149.

Lebreton, L., \& Andrivon, D. (1998). French isolates of Phytophthora infestans from potato and tomato differ in phenotype and genotype. European Journal of Plant Pathology, 104, 583-594.

Lebreton, L., Lucas, J.-M., \& Andrivon, D. (1999). Aggressiveness and competitive fitness of Phytophthora infestans isolates collected from potato and tomato in France. Phytopathology, 89, 679-686.

Lee, T. Y., Simko, I., \& Fry, E. (2002). Genetic control of aggressiveness in Phytophthora infestans to tomato. Canadian Journal of Plant Pathology, 24, 471-480.

Legard, D. E., Lee, T. Y., \& Fry, W. E. (1995). Pathogenic specialization in Phytophthora infestans: aggressiveness on tomato. Phytopathology, 85, 1356-1361.

Lehtinen, A., Hannukkala, A., Anderson, B., Hermansen, A., Le, V. H., Naerstad, R., et al. (2008). Phenotypic variation in Nordic populations of Phythophthora infestans in 2003. Plant Pathology, 57, 227-234.

Malcolmson, J. F., \& Black, W. (1966). New R-genes in Solanum demissum and their complementary races of Phytophthora infestans (Mont.) de Bary. Euphytica, 15, 199-203.

Michalska, A. M., \& Pazio, M. (2005). Inheritance of tomato leaf resistance to Phytophthora infestans - new information based on laboratory tests on seedlings. Plant Breeding and Seed Science, 51, 31-42.

Mills, W. R. (1940). Phytophthora infestans on tomato. Phytopathology, 30, 830-839.

Müller, K. O., \& Black, W. (1952). Potato breeding for resistance to blight and virus diseases during the last hundred years. Zeitschrift für Pflanzenzüchtung, 31, 305-318.

Niks, R. E., Parlevliet, J. E., Lindhout, P., \& Bai, Z. (2011). Breeding crops with resistance to diseases and pests ( $\mathrm{p}$. 198). The Netherlands: Wageningen Academic Publishers.

Nowakowska, M., Nowicki, M., Kłosińska, U., Maciorowski, R., \& Kozik, E. U. (2014). Appraisal of artificial screening techniques of tomato of accurately reflect field performance of the late blight resistance. PLoS One, 9(10), 1-12.
Nowicki, M., Kozik, E. U. \& Foolad, M. R. (2013). Late blight of tomato. In: K. Rajeev, R. Tuberosa (eds.), Translational genomics for crop breeding. Volume I: Biotic stresses, First Edition (pp. 241-265). Wiley.

Oyarzun, P. J., Pozo, A., Ordonez, M. E., Doucett, K., \& Forbes, G. A. (1998). Host specificity of Phytophthora infestans on tomato and potato in Ecuador. Phytopathology, 88, 265-271.

Perez, W. G., Gamboa, J. S., Falcon, Y. V., Coca, M., Raymundo, R. M., \& Nelson, R. J. (2001). Genetic structure of Peruvian populations of Phytophthora infestans. 2001. Phytopathology, 91(10), 956-965.

Plich, J., Tatarowska, B., Lebecka, R., Śliwka, J., ZimnochGuzowska, E., \& Flis, B. (2015). R2-like gene contributes to resistance to Phytophthora infestans in polish potato cultivar Bzura. American Journal of Potato Research, 92(3), 350-358.

Skidmore, D. I., \& Shattock, R. C. (1985). Monitoring of virulence in population of Phytophthora infestans using a Schwarzbach spore trap. Phytopathologische Zeitschrift, $113,141-149$.

Śliwka, J., Sobkowiak, S., Lebecka, R., Avendaño-Córcoles, J., \& Zimnoch-Guzowska, E. (2006). Mating type, virulence, aggressiveness and metalaxyl resistance of Phytophthora infestans in Poland. Potato Research, 49, 531-539.

Świeżyński, K. M., Domański, L., Zarzycka, H., \& ZimnochGuzowska, E. (2000). The reaction of potato differentials to Phytophthora infestans isolates collected in nature. Plant Breeding, 119, 119-126.

Vega-Sánchez, M. E., Erselius, L. J., Rodriguez, A. M., Bastidas, O., Hohl, H. R., Ojiambo, P. S., et al. (2000). Host adaptation to potato and tomato within the US-1 clonal lineage of Phytophthora infestans in Uganda and Kenya. Plant Pathology, 49, 531-539.

Wilson, J. B., \& Gallegly, M. E. (1955). The interrelationship of potato and tomato races of Phytophthora infestans. Phytopathology, 45, 473-476.

Zarzycka, H. (1995). Effect of culturing Phytophthora infestans on various substrates on expression of its virulence and aggressiveness to potato. Phytopathologia Polonica, 9(XXI), 8188.

Zarzycka, H. (1996). Effect of various methods of maintenance of Phytophthora infestans on its pathogenicity to potato. Plant Breeding and Seed Science, 40, 31-43.

Zarzycka H. (2001). Evaluation of resistance to Phytophthora infestans in detached leaflet assay. Preparation of the inoculum. In: E. Zimnoch-Guzowska, J. Syller, M. Sieczka (eds.), The methods of evaluation and selection applied in potato research and breeding (75-77). Monografie i rozprawy naukowe 10a/2001. IHAR Radzików. 